\title{
Effect of temperature on the permeability of lava dome rocks from the 2004-2008 eruption of Mount St. Helens
}

\author{
H. Elizabeth Gaunt ${ }^{1,2} \cdot$ Peter R. Sammonds ${ }^{1,3}$ • Philip G. Meredith ${ }^{1} \cdot$ Amy Chadderton $^{3}$
}

Received: 24 September 2015 / Accepted: 8 March 2016/Published online: 19 March 2016

(C) The Author(s) 2016. This article is published with open access at Springerlink.com

\begin{abstract}
As magma ascends to shallow levels in the volcanic conduit, volatile exsolution can produce a dramatic increase in the crystal content of the magma. During extrusion, low porosity, highly crystalline magmas are subjected to thermal stresses which generate permeable microfracture networks. How these networks evolve and respond to changing temperature has significant implications for gas escape and hence volcano explosivity. Here, we report the first laboratory experimental study on the effect of temperature on the permeability of lava dome rocks under environmental conditions designed to simulate the shallow volcanic conduit and lava dome. Samples were collected for this study from the 2004 2008 lava dome eruption of Mount St. Helens (Washington State, USA). We show that the evolution of microfracture networks, and their permeability, depends strongly on temperature changes. Our results show that permeability decreases by nearly four orders of magnitude as temperature increases from room temperature to $800{ }^{\circ} \mathrm{C}$. Above $800{ }^{\circ} \mathrm{C}$, the rock samples become effectively impermeable. Repeated cycles of heating leads to sample compaction and a reduction in fracture density and therefore a decrease in permeability. We argue that changes in eruption regimes from effusive to explosive
\end{abstract}

Editorial responsibility: K.V. Cashman

H. Elizabeth Gaunt

elizabeth.gaunt.09@ucl.ac.uk

1 Rock \& Ice Physics Laboratory, Department of Earth Sciences, University College London, London WC1E 6BT, UK

2 Now at Instituto Geofisico, Escuela Politecnica Nacional, Quito, Ecuador

3 Institute for Risk and Disaster Reduction, University College London, London WC1E 6BT, UK activity can be explained by strongly decreasing permeability caused by repeated heating of magma, conduit walls and volcanic plugs or domes. Conversely, magma becomes more permeable as it cools, which will reduce explosivity.

Keywords Permeability · Mount St Helens · Fractures · Outgassing $\cdot$ Lava domes

\section{Introduction}

Escape of volatiles from volcanic systems is critically important for determining the potential explosivity (Sparks 1997; Woods and Koyaguchi 1994). As magma rises in the conduit, gas exsolution may cause crystallization and rheological stiffening of silicic magma (e.g., Cordonnier et al. 2012; Lavallée et al. 2007; Martel and Schmidt 2003; Sparks 1997; Smith et al. 2011). Thermal stresses within the crystalline magma cause both differential and anisotropic expansion and contraction of the constituent crystals, where contraction produces a network of pervasive microfractures (e.g., Cooper and Simmons 1977; Fredrich and Wong 1986; Heap et al. 2014; Nara et al. 2010). Microfractures may form the dominant porosity in dense, degassed magma that forms lava spines such as those seen at Mount St. Helens (MSH) (Scott et al. 2008; Pallister et al. 2013) or volcanic plug rocks that often form before vulcanian events such as those seen at Tungurahua (Hall et al. 1999); microfractures dominate the microstructure (Pallister et al. 2013). Under these conditions, fluid movement through the crystallizing magma depends more on the development of the permeable fracture network and less on the expansion and coalescence of bubbles (Gaunt et al. 2014). There are multiple factors that influence the magnitude and direction of fluid movement (e.g., Gaunt et al. 2014; Lavallee et al. 2013; Nara et al. 2010). Temperature is one such factor, 
as changes in temperature can dramatically alter the physical and mechanical properties of the rock (e.g., Balme et al. 2004; Richter and Simmons 1974; Rocchi et al. 2004; Smith et al. 2011; Zharikov et al. 2003). Heating and cooling of rock samples generates microfractures through thermal expansion and contraction (e.g., Fredrich and Wong 1986; Richter and Simmons 1974). Subsequent changes in temperature can then act to either close or open the fractures, particularly when differential thermal stresses are generated by expansion and contraction of different minerals (Cooper and Simmons 1977). Microfractures are closed when the confining pressure is increased (e.g., Nara et al. 2010; Vinciguerra et al. 2005). However, the combined effect of pressure and temperature changes on the rock microstructure is not straightforward. The environmental conditions within volcanic systems evolve with time. Large changes in temperature and pressure will significantly alter the microstructure of the magma, which in turn alters the fluid flow properties and affects gas loss from the volcanic conduit. When these changes reduce permeability, gas overpressure can increase, and in turn increase the possibility of an explosive eruption; when these changes increase permeability, gases may escape more freely, and subsequent eruptions will be effusive (e.g., Melnik and Sparks 1999). Volcanic conduits are also subjected to repeated intrusion by magma, which causes cyclic heating and cooling of the conduit walls and dome rock above (Kennedy et al. 2010; Wooster and Kaneko 1998).

While earlier research has emphasized the importance of permeability in volcanic systems (e.g., Eichelberger et al. 1986; Sparks 1997), to date, the effect of temperature on permeability has not been addressed. By contrast, numerous room temperature permeability measurements have been reported for extrusive volcanic rocks such as lava blocks from Mt. Pelee, Colima, and Unzen (e.g., Bernard et al. 2007; Heap et al. 2015; Kendrick et al. 2013; Mueller et al. 2005). Additionally, a handful of studies have assessed the temporal changes in the permeability of hydrothermal systems at constant temperatures (Moore et al. 1994; Morrow et al. 2001) or under combined high pressure and temperature conditions (30 to $150 \mathrm{MPa}$ and up to $600{ }^{\circ} \mathrm{C}$ ) (Zharikov et al. 2003).

This present paper builds on our previous study of permeability, which was conducted on a suite of rocks representing a profile across the magmatic conduit at MSH. We showed that in highly crystalline magmas, fracture networks control not only the magnitude but also the location and direction of fluid movement (Gaunt et al. 2014). We found that permeability was highly anisotropic in the shear fractured rocks at conduit margins, but broadly isotropic in the column interior. However, since the temperature of these crystal-rich silicic magmas was $\leq 900{ }^{\circ} \mathrm{C}$ (Thornber et al. 2008), it is important to understand the effect of temperature on permeability in such systems. In this paper, we present results on the effect of temperature on the microstructure and permeability of lava dome rocks from the 2004-2008 eruption of MSH. Experiments were conducted at conditions appropriate for the upper volcanic conduit and lava dome (confining pressure of $10 \mathrm{MPa}$, temperatures $\leq 900{ }^{\circ} \mathrm{C}$ and fluid pressures of $5 \mathrm{MPa}$ ). For this study, we examine microfracture development within undeformed dome rocks from the conduit interior (Gaunt et al. 2014) to understand the influence of magma temperature on gas movement through microfracture networks. We combine dilatometry and thermal stressing tests with measurements of acoustic emission (AE) and elastic wave velocities to evaluate the damage caused by cycles of heating and cooling. Fracture density analysis and 2D porosity obtained by digital image analysis were used to estimate changes in the microstructure due to heating. We discuss our results in the context of gas loss and generation of gas overpressures.

\section{Mount St. Helens}

Mount St. Helens (MSH), Washington, USA is situated at $46^{\circ}$ $11^{\prime} 28.32^{\prime \prime} \mathrm{N}, 122^{\circ} 11^{\prime} 39.84^{\prime \prime} \mathrm{W}$ within the Cascade mountain range of the Pacific Northwest. The volcano comprises one main stratocone and is one of the most active volcanoes in the Cascade Range. MSH has experienced multiple episodes of both explosive and effusive eruptions (Clynne et al. 2008). The edifice is approximately 300,000 years old, although the main cone was built during the last 2200 years. Volcanic activity has ranged from effusive outpourings of lava to violent explosive Plinian eruptions (Mullineaux and Crandell 1981). The edifice was built by a series of lava dome and lava flow eruptions while surrounding the volcano is an apron of deposits ranging from ash, pyroclastic flow, debris avalanches and lahar deposits (Clynne et al. 2008). Multiple phases of lava dome growth have occurred, the most recent of which lasted from 2004 to 2008 (Iverson et al. 2006; Scott et al. 2008). During this 5-year eruption, crystal-rich dacite magma was extruded almost continuously as a succession of seven gas-poor, solidified lava spines (Scott et al. 2008). The magma is thought to have solidified in the conduit at about $1 \mathrm{~km}$ deep (Iverson et al. 2006), thus the spine as it appears at the surface is inferred to represent the magmatic column within the upper conduit.

Experimental measurements provide insight into processes operating within the conduit. Spine 4 was the most prominent of the spines and formed a "whale-back" feature which was extruded between January and April 2005 (Scott et al. 2008). Thermal monitoring of the spine extrusion by the US Geological Survey (USGS) Cascades Volcano Observatory (CVO) revealed temperatures as high as $700{ }^{\circ} \mathrm{C}$ within basal fractures and crystallization temperatures of between 850 and $900{ }^{\circ} \mathrm{C}$ as measured by Fe-oxide thermobarometry of samples from Spine 4 (Thornber et al. 2008). 


\section{Sample material}

Samples of intact, massive dacite from a collapsed section near to the center of Spine 4 were collected during a field campaign in August 2010. Near-continuous monitoring of the eruption by the USGS CVO allows the eruption date of the sample material to be estimated as 28 January 2005 . The sample block used for the tests presented here consists of a generally massive but locally flow-banded crystal-rich dacite containing approximately $65 \mathrm{wt} . \% \mathrm{SiO}_{2}$ and $50 \%$ vol. phenocrysts of plagioclase, amphibole, and pyroxene set in a microlite groundmass, giving a total crystal content of nearly $100 \%$ (Pallister et al. 2008).

\section{Microstructural analysis and observations}

Polished sections of dense dacite samples were prepared for microstructural analysis by scanning electron microscope (SEM) (Fig. 1). Complementary image analysis allowed us

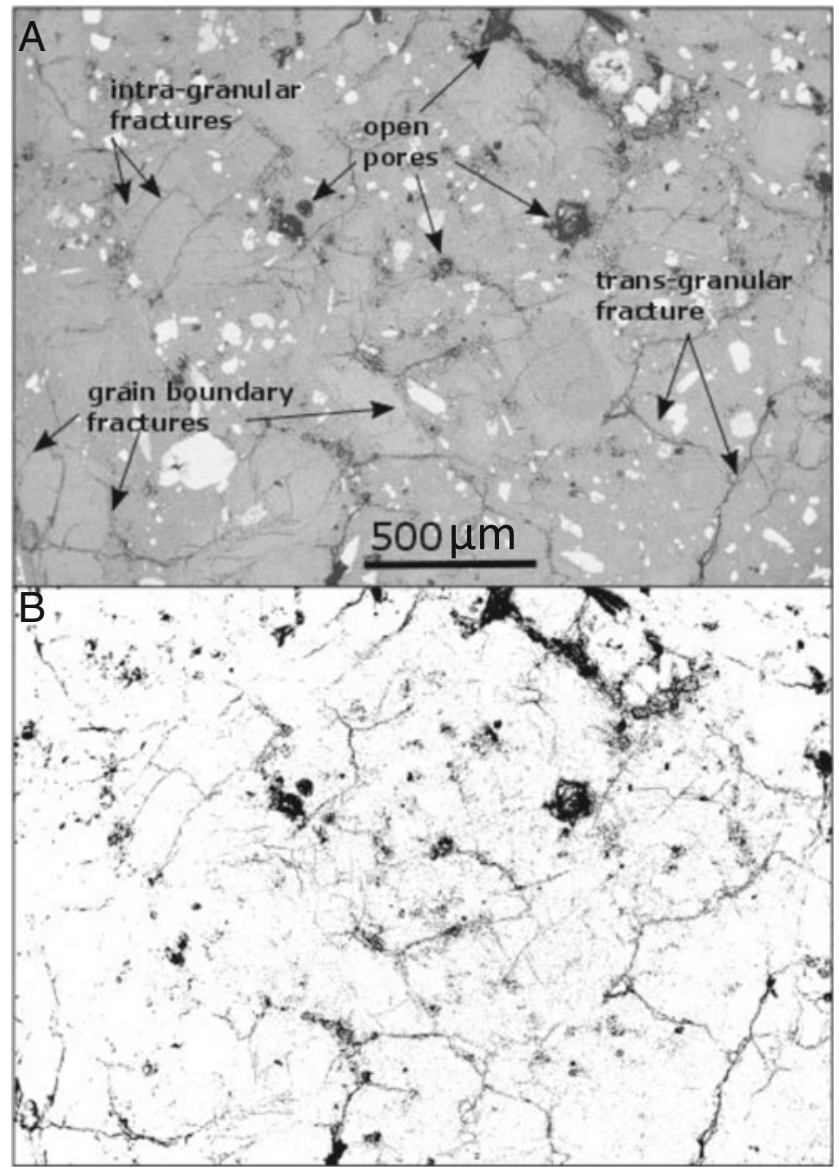

Fig. 1 a Scanning electron microscope backscatter photomicrograph of a sample of intact dacite showing a pervasive microfracture network with no obvious or preferred orientation. Large and small isolated pores are also present in the sample and are labeled on the image. Microstructural elements are labeled respectively. Image was taken in the $X Y$ plane (perpendicular to fluid flow). b Corresponding binary image of the SEM image converted using ImageJ. Black areas represent porosity to estimate both fracture density and $2 \mathrm{D}$ porosity (Fig. 1b) using fracture density analysis (Griffith et al. 2010) and an open-source image processing software ImageJ. Fracture networks were traced in Illustrator and analyzed using MATLAB (Griffith et al. 2010; Rempe et al. 2014) to calculate fracture density, the results of which are shown in Table 1. Connected porosity was determined using the imbibition method, which compares the mass of air-dry and water-saturated samples. Average measured connected porosity is low, at $6.0 \%$ (Table 1). This is in good agreement with the $2 \mathrm{D}$ porosity which was estimated as $6.7 \%$.

Our sample material contains two types of porosity: open pores and microfractures. The pores are mostly quasispherical and $<100 \mu \mathrm{m}$ in diameter, but with sparse elongated pores with long axes $\leq 400 \mu \mathrm{m}$ (Fig. 1). Most pores are isolated, but some are connected by microfractures. Microfractures exhibit three forms: grain boundary fractures, intragranular fractures and transgranular fractures. Grain boundary fractures are most commonly found around plagioclase phenocrysts, while intragranular fractures are most common within the plagioclase phenocrysts (Fig. 1). Both have lengths $<300 \mu \mathrm{m}$ and apertures $<10 \mu \mathrm{m}$. The transgranular fractures tend to be longer, some $>1 \mathrm{~mm}$, and with larger apertures $(<50 \mu \mathrm{m})$. Microfracture density is approximately $7.5 \mathrm{~mm} / \mathrm{mm}^{2}$.

\section{Physical properties of the sample material}

\section{Acoustic wave velocities}

For our permeability study, it was important to establish the relative isotropy or anisotropy of our sample material. We therefore measured radial P-wave velocities every $10^{\circ}$ around the circumference of cylindrical core samples (using the pulse transmission technique of Sammonds et al. 1989). If the starting material is anisotropic, then cracking caused by

Table 1 Summary of the measured physical properties of our massive dacite sample

\begin{tabular}{ll}
\hline Property & Value \\
\hline Density $\left(\mathrm{kg} / \mathrm{m}^{3}\right)$ & $2500 \pm 10$ \\
Connected Porosity (\%) & $6.0 \pm 0.1$ \\
2D Porosity (\%) & 6.7 \\
Maximum P-wave velocity $(\mathrm{m} / \mathrm{s})$ & 2710 \\
Minimum P-wave velocity $(\mathrm{m} / \mathrm{s})$ & 2580 \\
Mean permeability $\left(\mathrm{m}^{2}\right)^{\mathrm{a}}$ & $3.40 \times 10^{-16}$ \\
Average Fracture Density $\left(\mathrm{mm} / \mathrm{mm}^{2}\right)$ & 7.5 \\
\hline
\end{tabular}

${ }^{\mathrm{a}}$ Measured at $10 \mathrm{MPa}$ confining pressure, $5 \mathrm{MPa}$ pore fluid pressure, and room temperature 
thermal stressing during heating is likely to be aligned with anisotropy planes. Likewise, if the samples are isotropic then cracking because of thermal stressing is likely to be isotropically distributed (David et al. 1999).

Figure 2 shows that the $\mathrm{P}$-wave velocity is essentially isotropic, with less than $5 \%$ anisotropy. This result supports our SEM observation of an essentially isotropic distribution of microfractures (Fig. 1). Water permeability measurements made at room temperature and an effective pressure of $10 \mathrm{MPa}$ also show that permeability is independent of sample orientation (Gaunt et al. 2014), indicating that the fluid transport properties of this lava dome block are also broadly isotropic.

\section{Heat treatment and acoustic emissions}

Since we are investigating permeability at high temperature, it is important to know how the sample material behaves during heating and cooling. We therefore performed heat treatment tests, combined with acoustic emission (AE) measurements and elastic wave velocity measurements, to characterize this behavior and any associated microstructural changes in the material. AE measurements were used to monitor cracking activity during cyclic heating and cooling of the rock samples. Dacite samples, $25 \mathrm{~mm}$ in diameter and $50 \mathrm{~mm}$ in length, were located in a holder placed inside a horizontal tube furnace. The sample holder also acts as a wave guide to conduct acoustic signals to a 1-MHz piezoelectric transducer mounted outside the furnace. The AE output is logged continuously, while sample temperature is measured by a thermocouple attached to the sample surface. Samples were heated at $1{ }^{\circ} \mathrm{C} / \mathrm{min}$ to minimize thermal gradients and ensure that only thermal expansion and contraction of mineral crystals was responsible for the generation of fractures (Smith et al. 2011). Samples were held at the maximum temperature for $60 \mathrm{~min}$, and then cooled to ambient temperature at $1{ }^{\circ} \mathrm{C} / \mathrm{min}$. The experiment consisted of nine cycles of heating/cooling where the maximum temperature of each cycle was increased in $100^{\circ} \mathrm{C}$ steps starting at $100{ }^{\circ} \mathrm{C}$ and increasing up to $900{ }^{\circ} \mathrm{C}$. Between each heating cycle, the axial $\mathrm{P}$ and $\mathrm{S}$-wave velocities were measured to track microstructural changes in the sample.

The results show that there are significantly more AE hits and $\mathrm{AE}$ energy released during the cooling phase than during the heating phase (Fig. 3a). The maximum AE event rate during heating is approximately 700 hits per minute, but this increases during cooling to 5500 hits per minute. A step is observed in the cumulative AE energy curve at $420^{\circ} \mathrm{C}$ during heating, and little more energy is released above this temperature (Fig. 3b). During cooling, a large peak in AE hit rate occurred at around $490^{\circ} \mathrm{C}$, although these must be small amplitude signals as there is no corresponding step in the $\mathrm{AE}$ energy curve at this temperature.

The acoustic wave velocity measurements show that both $\mathrm{P}$ and S-wave velocities decreased as the sample was heated and reached a minimum at around 500 to $600{ }^{\circ} \mathrm{C}$ (Fig. 3c). Further heating causes acoustic velocities to increase at temperatures up to the maximum heat treatment temperature of $900{ }^{\circ} \mathrm{C}$. These observations suggest that significant thermal cracking occurs below $500-600^{\circ} \mathrm{C}$, but that plastic recovery processes dominate at higher temperatures. Even at the highest temperature however, the velocities never recover their initial values, suggesting that some irreversible crack damage remains in the sample (Fig. 3c). This scenario is entirely consistent with the $\mathrm{AE}$ measurements, where we observe increasing activity until $500{ }^{\circ} \mathrm{C}$ and then a dramatic fall-off in activity at higher temperatures.

The P- and S-wave velocity measurements between the cycles of thermal stressing do not directly correlate with the results of the permeability tests. An increase in the fracture density due to thermal stressing shown by the decrease in $\mathrm{P}$
Fig. 2 Azimuthal P-wave velocity measurements made every $10^{\circ}$ around cylindrical core samples, measured using the pulse transmission technique on two samples of massive dacite. The fracture network anisotropy is shown to be low, at less than $5 \%$ in both samples measured

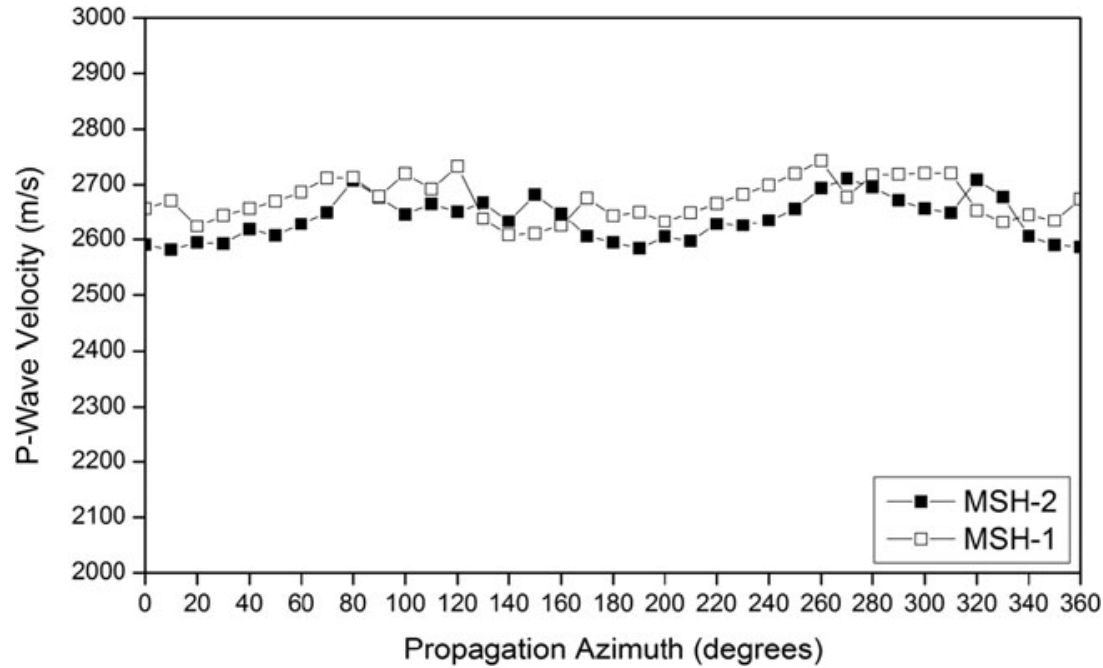




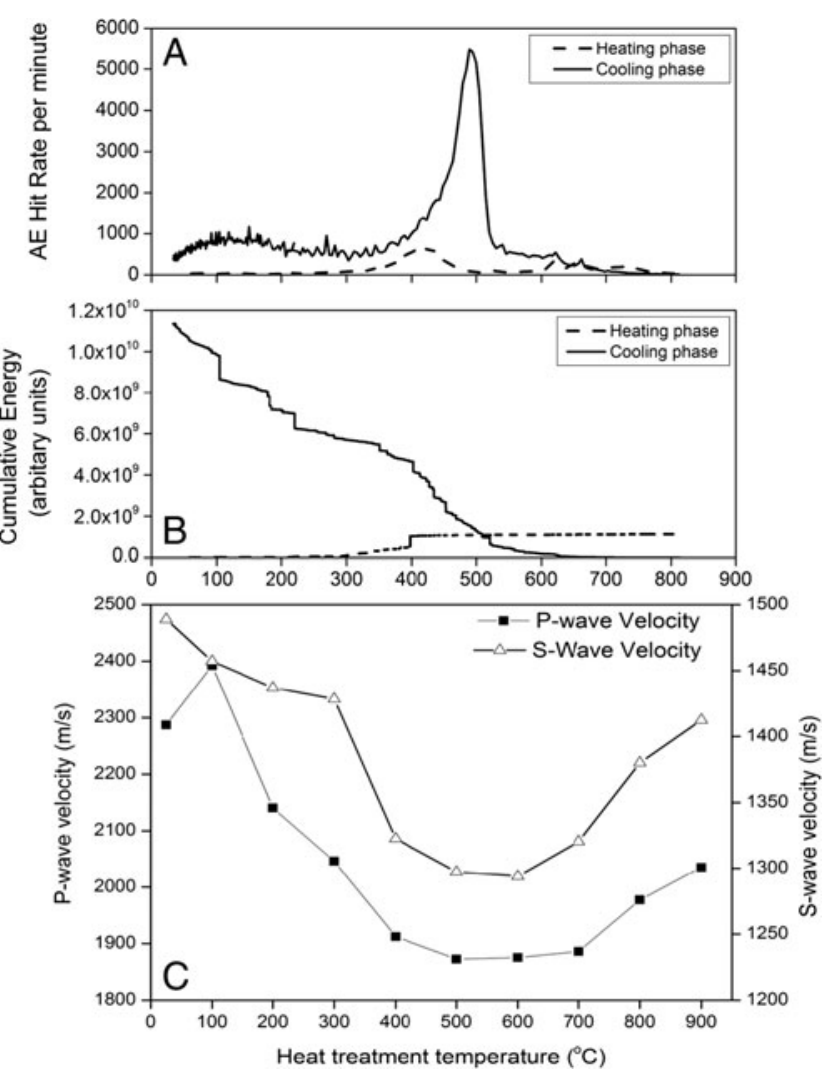

Fig. 3 a Acoustic emission (AE) hit rate as a function of temperature during heating (dashed line) and cooling (solid line) for the $800{ }^{\circ} \mathrm{C}$ heating/cooling cycle. There is significantly more AE during cooling than during heating and the event rate peaks at $490{ }^{\circ} \mathrm{C}$. b Cumulative energy release as a function of temperature during heating (dashed line) and cooling (solid line). Significantly more energy is released during the cooling cycles than the heating. During heating, at temperatures above $400{ }^{\circ} \mathrm{C}$, there is little to no energy released suggesting AE hits were low amplitude. It should be noted that cumulative energy is a dimensionless number as it is just a measure of the area under the waveform. $\mathbf{c}$ P and Swave velocities as a function of heat treatment temperature, measured between each heating/cooling cycle of the heat treatment tests. Both P and S-wave velocities follow the same trend, first decreasing between room temperature and $400{ }^{\circ} \mathrm{C}$, relatively constant between 500 and $700{ }^{\circ} \mathrm{C}$ then increasing again up to $900{ }^{\circ} \mathrm{C}$. The velocity does not return to its starting value

and S-wave velocities (Fig. 3c) should correlate with an increase in permeability (e.g., Vinciguerra et al. 2005). Equally, increasing $\mathrm{P}$ and $\mathrm{S}$-wave velocities represent a decreasing fracture density and should correlate with a decrease in permeability. However, the P and S-wave velocity measurements were done at room temperature and so cannot be directly compared to the permeability test results, which were performed at high temperature.

\section{Thermal expansion}

The amount by which a sample expands and contracts when heated or cooled will affect the physical properties of the sample and is therefore likely to affect fluid movement (e.g., Richter and Simmons 1974). The thermal expansion coefficients of MSH dacite samples were therefore measured using a dilatometer in the Earth, Ocean and Ecological Sciences Department at the University of Liverpool. Samples comprising 6-mm diameter cores of massive dacite were placed between two ceramic pistons within the dilatometer furnace and a small axial load of $3 \mathrm{~N}$ applied. A displacement transducer measured the sample length change during a series of heating and cooling cycles. Samples were heated at a rate of $5^{\circ} \mathrm{C} / \mathrm{min}$ to $100^{\circ} \mathrm{C}$, left to dwell for $30 \mathrm{~min}$ and then cooled at $5^{\circ} \mathrm{C} / \mathrm{min}$. The maximum temperature of each cycle was increased in $100{ }^{\circ} \mathrm{C}$ steps up to $900{ }^{\circ} \mathrm{C}$.

Results from this experiment showed that samples expanded during heating and contracted during cooling, entirely as
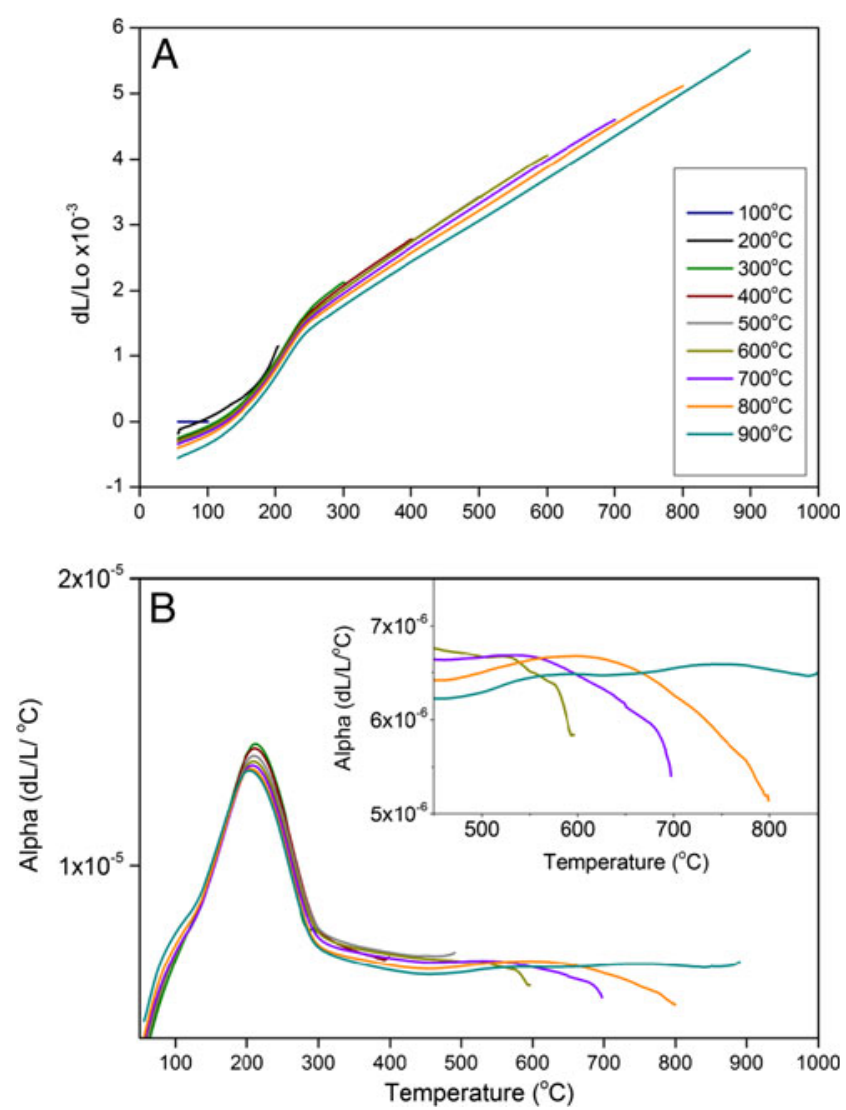

Fig. 4 a Thermal expansion curves from dilatometer tests during cyclical heating in $100^{\circ} \mathrm{C}$ increments up to $900^{\circ} \mathrm{C}$, on a sample of massive dacite. The samples contracted by increasing amounts after each heating phase as shown by the increasingly negative starting value of $\mathrm{dL} / \mathrm{Lo} \times 10^{-3}$. Between 100 and $300{ }^{\circ} \mathrm{C}$, the non-linear rate is caused by the nonlinear heating rate of the furnace and is not due to changes in the expansion of the sample. b Thermal expansion coefficient (alpha) or strain rate/temperature as a function of temperature measured during cyclical heating of a sample of massive dacite. Between 100 and $300{ }^{\circ} \mathrm{C}$, the non-linear heating and control of the furnace causes fluctuations in the data and should be ignored. Inset is a zoomed in section of the important changes in strain rate as a function of temperature that occur above $500{ }^{\circ} \mathrm{C}$ 
expected (Fig. 4a). However, each successive heating and cooling cycle caused an increase in sample contraction so that the measured length change became increasingly more negative. Above $300^{\circ} \mathrm{C}$, the length change is linear as a function of temperature for all of the heating/cooling cycles. Below $300^{\circ} \mathrm{C}$, the length change appears to be non-linear and the rate of change decreases between 200 and $100^{\circ} \mathrm{C}$. This is attributed to the non-linear heating rate of the furnace at low temperatures and not to processes occurring within the sample. Equally, the strain cycles (Fig. 4b) measured for the thermal expansion curves on the $600{ }^{\circ} \mathrm{C}$ heating cycle show a rapid decrease in the strain rate beginning at $520{ }^{\circ} \mathrm{C}$. The strain rate decreases further at $580{ }^{\circ} \mathrm{C}$. On the following two consecutive heating cycles $\left(700\right.$ and $\left.800^{\circ} \mathrm{C}\right)$, this deviation in the strain rate still occurs, but to a lesser extent, and does not occur at all during the $900{ }^{\circ} \mathrm{C}$ heating cycle. From these observations, we infer that the expansion during heating involves substantial microcrack formation that is not recoverable during cooling.

\section{High temperature permeability measurements}

\section{Methods}

We performed steady-state flow permeability measurements on massive dacite samples at temperatures from ambient to $900{ }^{\circ} \mathrm{C}$ under an effective pressure of $5 \mathrm{MPa}$. This effective pressure comprises a confining pressure $(\mathrm{Pc})$ of $10 \mathrm{MPa}$ and a pore fluid pressure $(\mathrm{Pp})$ of $5 \mathrm{MPa}$; the simple effective pressure (Peff) is then calculated as Peff $=\mathrm{Pc}-\alpha \mathrm{Pp}$, in which the poroelastic constant $\alpha$ is assumed to be 1 . All measurements were made using our high-pressure, permeameter and pore volumometer system (described in Benson et al. 2003), which is close-coupled to a high-temperature triaxial deformation cell (designed and built at University College London and described in Rocchi et al. 2004). The deformation cell comprises a pressure vessel $(500 \mathrm{~mm}$ long by $96 \mathrm{~mm}$ internal diameter) pressurized with argon gas provided via an airdriven gas booster; it has a working pressure limit of $100 \mathrm{MPa}$ and is equipped with an insulated two-zone internal furnace (with a maximum operating temperature of $1200^{\circ} \mathrm{C}$ ). Temperature is measured by thermocouples placed next to the sample, calibrated against an instrumented dummy sample. For the current study, the cell was operated in hydrostatic mode without any differential stress.

Cylindrical test specimens were cored from a single block of massive dacite to $25 \mathrm{~mm}$ in diameter and cut to $50 \mathrm{~mm}$ in length (with the ends ground flat and parallel to better than $0.01 \mathrm{~mm}$ ). These sample dimensions were chosen to provide the aspect ratio greater than 1:1 required for valid permeability data while also being short enough to minimize the temperature gradient across the sample during high temperature tests. Prior to testing, each specimen was vacuum-saturated with water then sealed between platens inside a metal jacket. This specimen assembly was placed within the furnace inside the cell. Aluminum jackets were used for tests run at $100{ }^{\circ} \mathrm{C}$ to $500{ }^{\circ} \mathrm{C}$ and mild steel jackets for tests run from 600 to $900^{\circ} \mathrm{C}$. To conduct an experiment, the confining pressure was applied first, followed by the pore fluid pressure. Following pressurization, the sample was heated to the test temperature at $5{ }^{\circ} \mathrm{C} /$ min. The fluid in the system (both in the sample and in the associated small-bore piping) was allowed to expand and flash to steam while the sample was heated, and the system was then left to thermally equilibrate for ca. $120 \mathrm{~min}$. Permeability measurements were made once equilibration was reached (i.e., all the thermocouple readings became constant and the pore fluid had ceased to expand) by applying a differential pore fluid pressure of 0.25 to $0.50 \mathrm{MPa}$ across the sample, while maintaining the mean pore fluid pressure at $5 \mathrm{MPa}$. The differential pore fluid pressure induces fluid flow. The flow rate is at first transient but reaches steady state after some interval of time which depends on the sample permeability.

At the set pore fluid pressure of $5 \mathrm{MPa}$, liquid water undergoes a phase change to steam at $263{ }^{\circ} \mathrm{C}$. So above this test temperature, the liquid water injected into one end of the sample flashes to steam. Steam ejected from the other end of the sample then condenses to liquid water. The flash point and condensation point remain at fixed positions at either side of the sample so that a dynamic equilibrium is reached. The pore water is maintained at ambient temperature in both the upstream and downstream reservoirs of the permeameter, which is housed in a temperature-controlled laboratory. Under these conditions, the mass of the pore fluid (liquid water plus steam) is conserved. The volume change recorded in the volumometers is therefore a measure of the volume of fluid flowing through the sample, regardless of whether it is liquid water or steam. Hence, no corrections are required to compensate for the volume difference between steam and liquid water. These experimental conditions were specifically chosen so that the Klinkenberg and Forchheimer gas permeability corrections were not required (Tanikawa and Shimamoto 2009; Pazos et al. 2009). Our pore fluid (water) has a high molecular weight and we use a low fluid flow rate; hence, our fluid flow maintains a parabolic Poisuille velocity profile (i.e., Darcy flow). Permeability can therefore be calculated by direct application of Darcy's Law once steady state flow is achieved. However, while the fluid pressure gradient and the crosssectional area of the sample remain constant, the viscosity of the pore fluid changes significantly with increase in temperature. Therefore, the permeability for each temperature was calculated using the appropriate viscosity for that specific temperature (taken from standard steam tables).

We conducted two complementary series of tests to determine the effect of temperature on permeability. In the first series (series no. 1), the aim was to make permeability 
measurements over the full temperature range on the same sample in order to eliminate the effect of natural sample variability. Continuous measurements require the whole system, including the sample, to be maintained at very high temperature for multiple days. Because safety considerations militated against leaving the system at very high temperature when unattended overnight, the assemblage was cooled to room temperature between successive measurements. To test the effect of cooling the system on permeability, we conducted a second series of tests (series no. 2), where individual samples were heated directly to each successive temperature, and the permeability measured. For all tests in both series, the permeability of each specimen was measured at room temperature prior to heating to obtain a baseline value. In series no. 1, the permeability was measured in $100{ }^{\circ} \mathrm{C}$ steps from 100 to $900{ }^{\circ} \mathrm{C}$ and repeated on two individual specimens. This cycle of heating, measurement, and cooling was repeated until the maximum temperature $\left(900^{\circ} \mathrm{C}\right)$ had been achieved. In series no. 2 , the permeability of eight separate samples were measured at room temperature before they were heated directly to test temperatures of 100, 200, 300, 400, 500, 600, 700, 800, and $900{ }^{\circ} \mathrm{C}$, respectively, and their permeabilities measured at these temperatures.

\section{Results}

\section{Permeability}

Permeability results are shown in Fig. 5. The permeability of the MSH massive dacite at room temperature, varied from $3 \times 10^{-16}$ to $1 \times 10^{-15} \mathrm{~m}^{2}$ for all samples. By contrast, the permeability decreased by almost four orders of magnitude as the temperature was increased from ambient to $800{ }^{\circ} \mathrm{C}$. We also attempted to measure permeability at $900{ }^{\circ} \mathrm{C}$ but we were unable to record fluid flow through the specimens at this temperature over timescales less than $8 \mathrm{~h}$. This gives an upper bound to sample permeability at $900{ }^{\circ} \mathrm{C}$ of approximately $1 \times 10^{-19} \mathrm{~m}^{2}$.

The results from the series no. 1 tests are illustrated in Fig. 5a and show that permeability decreases by more than two orders of magnitude as temperature is increased from 100 to $300{ }^{\circ} \mathrm{C}$. This permeability change is followed by a more modest decrease between 300 and $500{ }^{\circ} \mathrm{C}$ and then an increase at $600{ }^{\circ} \mathrm{C}$. Between $600{ }^{\circ} \mathrm{C}$ and $800{ }^{\circ} \mathrm{C}$, there is a further permeability decrease of one to two orders of magnitude. Series no. 2 specimens show a similar trend of decreasing permeability over the whole temperature range except for an increase between 500 and $600{ }^{\circ} \mathrm{C}$ (Fig. 5b). However, the absolute values of permeability are an order of magnitude higher at $600{ }^{\circ} \mathrm{C}$ and above for the directly heated
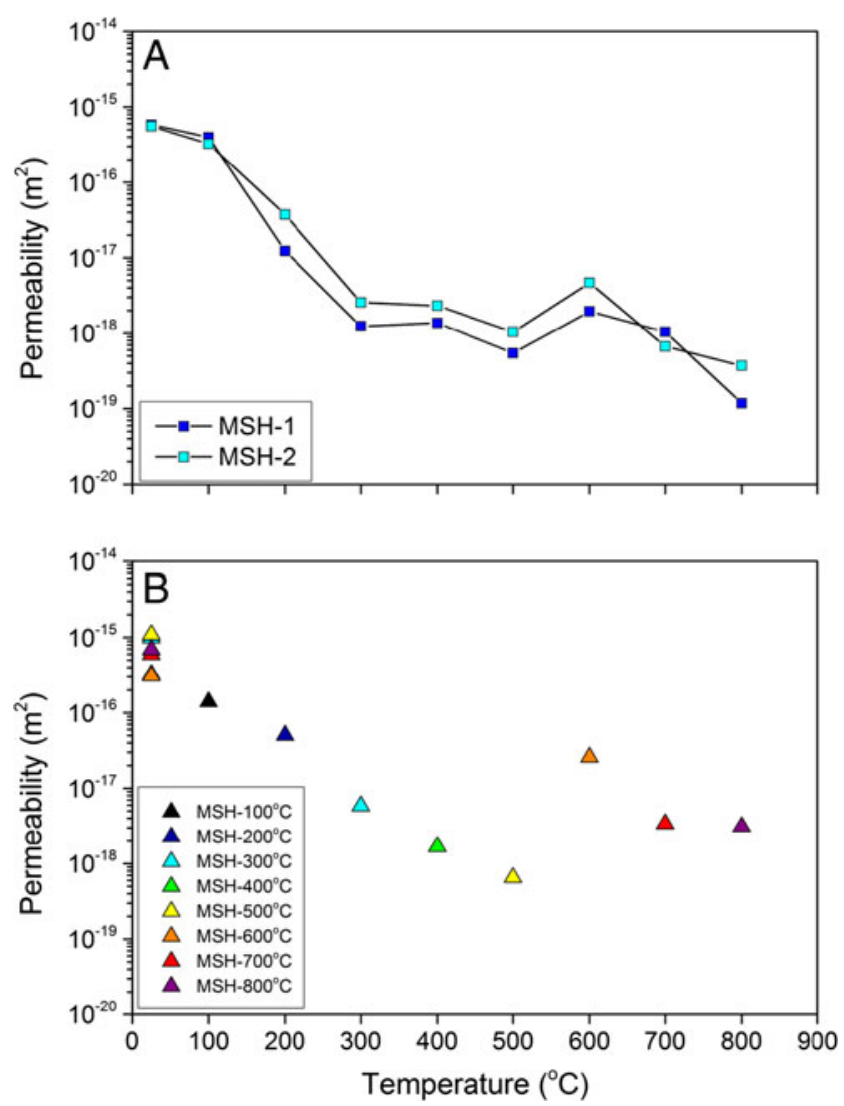

Fig. 5 High temperature permeability. a Measurements for permeability for samples from series no. 1 where permeability was measured in $100^{\circ} \mathrm{C}$ steps from 100 to $900^{\circ} \mathrm{C}$ on the two individual specimens. Permeability is shown to decrease by nearly four orders of magnitude as the temperature is increased. Experimental error for the permeability measurements was calculated and was less than $\pm 4 \%$. b Measurements of permeability for series no. 2 where samples were heated directly to single test temperatures of $100,200,300,400,500,600,700$, and $800{ }^{\circ} \mathrm{C}$

series no. 2 tests than for the cyclically heated series no. 1 tests.

\section{Fracture density and porosity analysis of SEM images}

SEM backscatter images of polished sections from samples subjected to high temperature permeability measurements (Fig. 6a, c) were analyzed for fracture density and 2D porosity (Fig. 6b, d), to compare to the fracture density and 2D porosity of the original sample material. Fracture densities in the pretest samples and post-test series no. 2 samples at $800{ }^{\circ} \mathrm{C}$ are similar at 7.5 and $6.5 \mathrm{~mm} / \mathrm{mm}^{2}$, respectively. The fracture density of a cyclically heated series no. 1 sample, however, is significantly less at $3.15 \mathrm{~mm} / \mathrm{mm}^{2}$. The $2 \mathrm{D}$ porosities of the post-test samples from series no. 1 and no. 2 are 2.1 and $5.5 \%$, respectively. The porosity of the series no. 1 post-test sample decreases from 6.7 to $2.1 \%$, which agrees well with the concordant reduction in fracture density. 


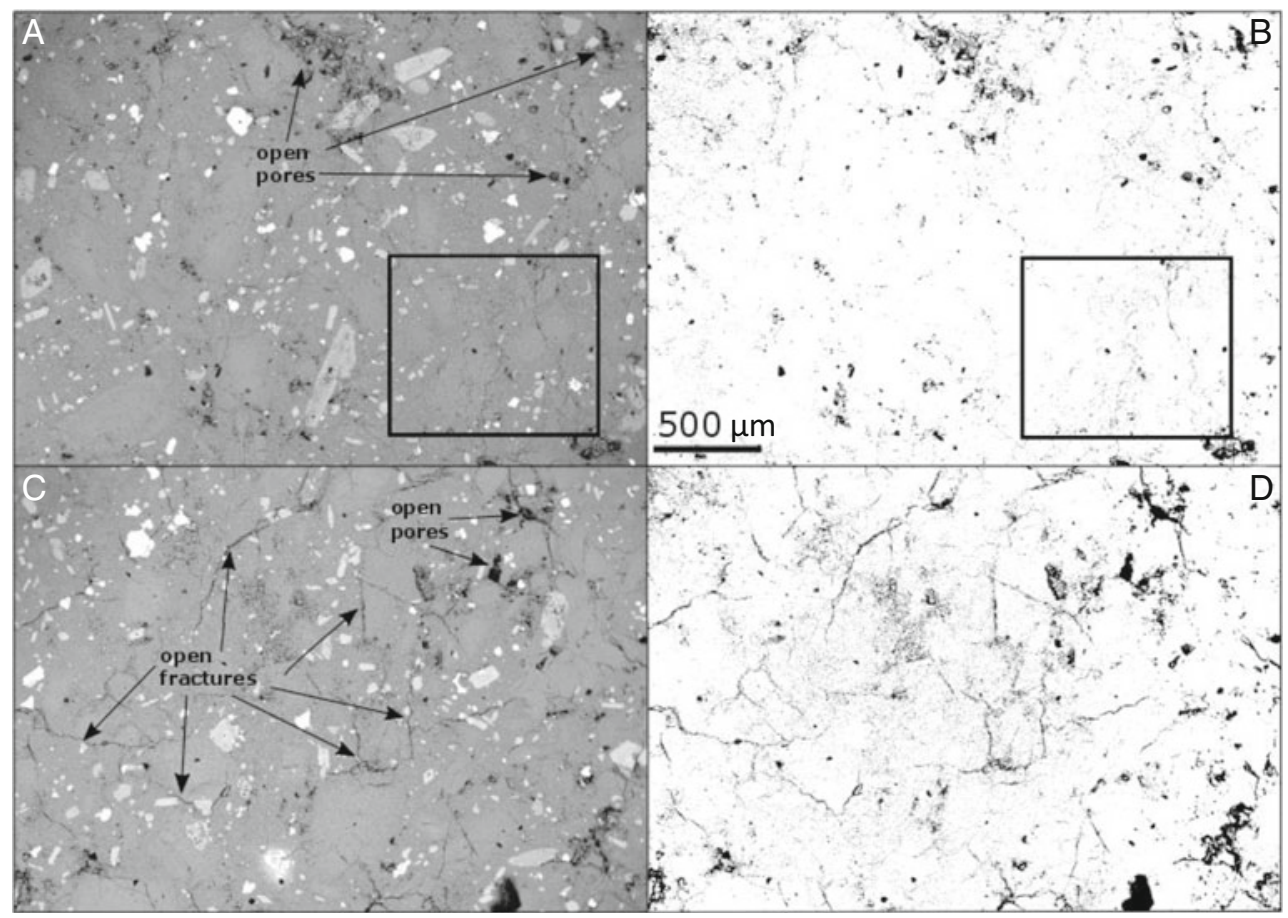

Fig. 6 Post-test scanning electron microscope backscatter photomicrographs (a, c) and corresponding binary images $(\mathbf{b}, \mathbf{d})$ made using open-source software ImageJ. Images were taken in the $X Y$ plane. a Photomicrograph of sample MSH-2 from series no. 1 post-test shows visibly reduced fracture networks after cyclical heating during permeability tests. Pores however remain and show very few signs of closure or deformation. Box shows area where remnants of fractures can be seen. b Corresponding binary image of MSH-2; black areas show remaining porosity. $\mathbf{c}$ Photomicrograph of sample MSH- 800 from series no. 2 which shows a high proportion of pores and fractures are still present after heating once to $800{ }^{\circ} \mathrm{C}$. Fractures remain and are still visibly open; these are labeled on the image. d Corresponding binary image of MSH-800; black areas represent porosity

\section{Discussion}

\section{Permeability in high temperature magma}

To our knowledge, these results represent the first systematic laboratory permeability measurements made on volcanic rock at the high temperature and moderate pressure conditions that typify shallow volcanic systems. Natural sample variability in the massive dacite is low and sample permeability at room temperature varies by only about a factor of 3 . In contrast, permeability is dramatically reduced by nearly four orders of magnitude when the temperature is increased from room temperature to $800{ }^{\circ} \mathrm{C}$. We also find that fluid flow is essentially immeasurable above this temperature, such that the rock becomes effectively impermeable over timescales equivalent to our experiments. There are a number of competing micromechanisms occurring during the heating process, including thermal expansion of mineral grains, thermallyinduced microcracking, rock-fluid chemical healing, and plastic deformation. At the lower temperatures tested $\left(\leq 300{ }^{\circ} \mathrm{C}\right)$, we expect the thermal expansion of the mineral matrix to dominate and close preexisting cracks (e.g., Cooper and Simmons 1977; Richter and Simmons 1974). Our thermal expansion data show that the dacite expands in a linear manner during heating. Matrix compressibility also increases, so that even under modest pressures, the aperture of preexisting cracks will decrease and will reduce both void volume and void connectivity (Richter and Simmons 1974), thus reducing permeability (Zharikov et al. 2003). At higher temperatures, we expect thermal cracking to increase in importance as higher thermal strain differences generate higher thermal stresses and an increased level of thermal cracking (Cooper and Simmons 1977). Both our AE data and our wave velocity data support this hypothesis. AE output increases significantly above $300{ }^{\circ} \mathrm{C}$, and wave velocities fall sharply (Fig. 3c). In this temperature range, crack closure due to thermal expansion is competing with crack opening due to thermal stresses, with the opening of new cracks dominating at higher temperatures (Cooper and Simmons 1977; Fredrich and Wong 1986). We therefore see that the rate of permeability reduction decreases above $300{ }^{\circ} \mathrm{C}$. The permeability reaches a minimum at around $500{ }^{\circ} \mathrm{C}$, and then increases at $600{ }^{\circ} \mathrm{C}$, as thermal cracking dominates. Above $600{ }^{\circ} \mathrm{C}$, the permeability again decreases. We suggest that this results from a combination of crack healing and crystal plasticity acting to close the thermal microcracks. 
Recent experimental studies (e.g., Meredith and Brantut 2015; Tenthorey et al. 2003) have shown that crack healing (strength recovery) and crack sealing (permeability reduction) in crystalline rocks can occur at much faster rates and lower temperatures than previously recognised, especially in rocks with a high silica content when pore water is present. Microcracks in water-saturated, silica-rich rocks can heal over timescales from a few hours to a few days at temperatures of $400-900{ }^{\circ} \mathrm{C}$ as measured by strength increases of up to $75 \%$ and permeability reduction of several orders of magnitude. That is exactly the situation we have in our experiments. We would also expect plastic deformation processes to become increasingly important at the highest temperatures. Taken together, the combination of healing and plasticity above $600^{\circ} \mathrm{C}$ should significantly reduce permeability and $\mathrm{AE}$ (cracking) activity and significantly increase elastic wave velocities. That is exactly what we see in our data.

A comparison of test results shows that the permeabilities of samples heated directly to their test temperature (series no. 2) were very similar to those of cyclically heated samples (series no. 1) at temperatures $\leq 500{ }^{\circ} \mathrm{C}$. Series no. 2 permeabilities are an order of magnitude higher for temperatures of $600{ }^{\circ} \mathrm{C}$ and above. Cyclic heating and cooling of our thermal expansion tests produced an increased amount of compaction after each sequential heating/cooling cycle, manifested as a reduction in sample length of the sample (Fig. 4a). This suggests that temperature cycling increased the matrix compressibility of our samples, as illustrated by post-test SEM image analysis (Fig. 6) of fracture density and 2D porosity. Microfracture density is reduced by more than a factor of $2\left(7.5\right.$ to $\left.3.2 \mathrm{~mm} / \mathrm{mm}^{2}\right)$ and $2 \mathrm{D}$ porosity is reduced by greater than a factor of 3 (6.7 to $2.1 \%$ ) in the samples that underwent cyclical heating (series no. 1). These decreases are substantially greater than those for the series no. 2 samples that were heated only once. For these latter samples, the fracture density was only slightly lower $\left(6.5 \mathrm{~mm} / \mathrm{mm}^{2}\right)$ and porosity decreased by less than 1.5 percentage points $(6.7$ to $5.5 \%)$. In summary, repeated temperature cycling appears to cause a sequentially larger reduction in the permeability as the microstructures are irreversibly altered through the repeated reductions in porosity and fracture connectivity by compaction or crack healing.

It is well established that increases in confining pressure reduce permeability via crack closure (under room temperature conditions) (e.g., Nara et al. 2010 and Vinciguerra et al. 2005). Equally, viscous densification under a constant differential stress can reduce permeability by pore and crack closure (Heap et al. 2015). Additionally, since elevated temperature also causes rock compressibility to increase (Zharikov et al. 2003) and strength to decrease (e.g., Smith et al. 2009), rocks in volcanic conduits are likely to be even more susceptible to large reductions in permeability through increases in confining pressure or stress.

\section{Implications for volcanic systems}

As crystal-rich magma begins to cool in the shallow conduit, thermal stresses produce microfracture networks that may increase magma permeability, making it easier for gas to escape, especially in low-porosity, highly crystalline magma. However, the permeability measured in this study can be considered relatively low compared to high permeability conduit margin fracture zones where the majority of gas flow occurs (Gaunt et al. 2014). Although this is true for MSH, in volcanic conduits where significant marginal fracturing does not occur, these microfracture networks are important for controlling gas flow and storage. The mechanism for the generation of gas overpressure before vulcanian events is thought to be the formation of a plug of dense, highly crystalline rocks at the top of the conduit. These plugs are suggested to restrict the flow of gas out of the magmatic column (Burgisser et al. 2010; Diller et al. 2006). However, our study suggests that the permeability of highly crystalline magma is likely to increase due to cracking as it rises and cools in the conduit. The implication is that the formation of a volcanic plug may not be the only mechanism responsible for gas pressure build up and vulcanian events.

Temperature conditions within the volcanic edifice can change through the intrusion of hot new magma in the conduit. An influx of hot magma will increase the temperature of the surrounding conduit wall rocks or the lava dome rocks (Wooster and Kaneko 1998; Kennedy et al. 2010). Equally, fluxing of hot gases through the system can cause short-term variations in temperature. Temperatures within fumaroles on active volcanoes have been found to be highly variable over relatively short periods of time. Daily fluctuations in temperature of over $100{ }^{\circ} \mathrm{C}$ were measured in fumarole fields on Volcan Colima, Mexico (Connor et al. 1993), while increases in fumarole temperature have also been correlated to seismic events on Merapi volcano, Indonesia (Richter et al. 2004). Results from our study show that even a small increase in ambient temperature $\left(50\right.$ to $\left.100^{\circ} \mathrm{C}\right)$ could reduce magma permeability by over an order of magnitude, and so restrict the ability of gases to escape from the ascending magma. This would lead to the trapping of gas and the generation of gas overpressures (e.g., Melnik and Sparks 1999; Sparks 1997, 2003).

Cyclical heating during the experiments caused fracture compaction in the massive dacite samples, which reduced permeability. We suggest that repeated intrusion of hot magma in the conduit could therefore cause the lava dome or the conduit walls to compact through the reduction of void volume and become increasingly impermeable with each subsequent intrusion. Where 
significant fracturing occurs at the conduit margin during magma ascent, as at MSH, it is unlikely that significant fracture compaction would occur and, by extension, that permeability would be reduced by increases in temperature alone. However, repeated reductions in the permeability of magma, conduit wall, or plug could significantly reduce the amount of gas that is able to escape and contribute to a change in the eruptive style, initiation of gas pressure accumulation, and an explosive eruption.

\section{Concluding remarks}

High temperature, hydrostatic permeability tests measured the effect of temperature on the permeable porous network of microfractures within the volcanic conduit. The experiments showed the following:

1. Permeability decreased by nearly four orders of magnitude when the samples were heated from room temperature to $800{ }^{\circ} \mathrm{C}$.

2. Above $800{ }^{\circ} \mathrm{C}$, the samples became essentially impermeable over the timescale of the experiment (approximately $8 \mathrm{~h}$ ). 3. Up to $500^{\circ} \mathrm{C}$, the permeability of samples heated only once followed the same trend as those repeatedly heated. Above $500{ }^{\circ} \mathrm{C}$, the permeability of the samples heated directly to the test temperature was consistently higher by an order of magnitude than those cyclically heated to the same temperature.

4. Thermal expansion tests by dilatometry showed increased compaction, manifested in a decrease in the measured length of the sample after each heating/cooling cycle.

5. Fracture density and 2D porosity were both substantially decreased in samples that were cyclically heated.

We conclude that temperature has an important effect on the permeability of these rocks and therefore the efficiency of gas loss from crystal rich magmas. Changing temperature conditions within the conduit can act to either increase (during cooling) or decrease (during heating) the permeability of the magma and surrounding rocks. This has implications for conditions that might generate gas overpressures and we advise caution in assuming that gas overpressures are necessarily caused by the solidification of plug rocks and domes, especially in highly crystalline magmas. Importantly, cyclical heating causes compaction that may contribute substantially to changing eruptive conditions, decreasing magma permeability over time. Decreasing permeability leads to increased gas retention either within the remaining pores or by reabsorption into the melt phase, which increases the potential for a change in eruption regime from effusive to explosive.
Acknowledgments We thank N. Hughes and S. Boon at UCL for technical assistance with the experiments; colleagues at LMU, Germany and UBC, Canada for fieldwork collaboration; C. Kilburn, R. Smith, and T. Mitchell at UCL and J. Pallister at USGS CVO for helpful discussions. Y. Lavallee at University of Liverpool is also thanked for assistance with the thermal expansion coefficient experiments. H.E.G. was supported by a UK Natural Environment Research Council research studentship. We thank Lori Kennedy, Ben Kennedy, and Mike Heap for constructive reviews that have improved the manuscript.

Open Access This article is distributed under the terms of the Creative Commons Attribution 4.0 International License (http:// creativecommons.org/licenses/by/4.0/), which permits unrestricted use, distribution, and reproduction in any medium, provided you give appropriate credit to the original author(s) and the source, provide a link to the Creative Commons license, and indicate if changes were made.

\section{References}

Balme MR, Rocchi V, Jones C, Sammonds PR, Meredith PG, Boon S (2004) Fracture toughness measurements on igneous rocks using a high-pressure, high-temperature rock fracture mechanics cell. J Volcanol Geotherm Res 132(2-3):159-172

Benson PM, Meredith PG, Platzman ES (2003) Relating pore fabric geometry to acoustic and permeability anisotropy in Crab Orchard Sandstone: a laboratory study using magnetic ferrofluid. Geophys Res Lett 30(19).

Bernard ML, Zamora M, Geraud Y, Boudon G (2007) Transport properties of pyroclastic rocks from Montagne Pelee volcano (Martinique, Lesser Antilles). J Geophys Res Solid Earth 112:16

Burgisser A, Poussineau S, Arbaret L, Druitt TH, Giachetti T, Bourdier J-L (2010) Pre-explosive conduit conditions of the 1997 vulcanian explosions at Soufrière Hills Volcano, Montserrat: I. Pressure and vesicularity distributions. J Volcanol Geotherm Res 194(1-3):27-41

Clynne MA, Calvert A, Wolfe E, Evarts R, Fleck R (2008) The Pleistocene eruptive history of Mount St. Helens, Washington, from 300,000 to 12,800 years before present. In: Sherrod D, Scott W, Stauffer P (eds) A Volcano Rekindled: The Renewed Eruption of Mount St. Helens, 2004-2006. p 593

Connor CB, Clement BM, Song X, Lane SB, West-Thomas J (1993) Continuous monitoring of high-temperature fumaroles on an active lava dome, Volcán Colima, Mexico: evidence of mass flow variation in response to atmospheric forcing. J Geophys Res 98(B11):1971319722. doi:10.1029/93JB02169

Cooper HW, Simmons G (1977) The effect of cracks on the thermal expansion of rocks. Earth Planet Sci Lett 36:404-412

Cordonnier B, Caricchi L, Pistone M, Castro J, Hess KU, Gottschaller S, Manga M, Dingwell DB, Burlini L (2012) The viscous-brittle transition of crystal-bearing silicic melt: direct observation of magma rupture and healing. Geology 40(7):611-614

David C, Menéndez B, Darot M (1999) Influence of stress-induced and thermal cracking on physical properties and microstructure of $\mathrm{La}$ Peyratte granite. Int J Rock Mech Min Sci 36(4):433-448

Diller K, Clarke AB, Voight B, Neri A (2006) Mechanisms of conduit plug formation: implications for vulcanian explosions. Geophys Res Lett 33(20):L20302

Eichelberger JC, Carrigan CR, Westrich HR, Price RH (1986) Nonexplosive silicic volcanism. Nature 323(6089):598-602

Fredrich JT, Wong TF (1986) Micromechanics of thermally induced cracking in three crustal rocks. J Geophys Res 91(B12):1274312764 
Gaunt HE, Sammonds PR, Meredith PG, Smith R, Pallister JS (2014) Pathways for degassing during the lava dome eruption of Mount St. Helens 2004-2008. Geology 42(11):947-950

Griffith WA, Nielsen S, Di Toro G, Smith SAF (2010) Rough faults, distributed weakening, and off-fault deformation. J Geophys Res 115:B08409. doi:10.1029/2009JB006925

Hall ML, Robin C, Beate B, Mothes P, Monzier M (1999) Tungurahua Volcano, Ecuador: structure, eruptive history and hazards. J Volcanol Geotherm Res 91(1):1-21

Heap MJ, Lavallée Y, Petrakova L, Baud P, Reuschlé T, Varley NR, Dingwell DB (2014) Microstructural controls on the physical and mechanical properties of edifice-forming andesites at Volcán de Colima, Mexico. J Geophys Res Solid Earth 119:2925-2963. doi: 10.1002/2013JB010521

Heap MJ, Farquharson JI, Wadsworth FB, Kolzenburg S, Russell JK (2015) Timescales for permeability reduction and strength recovery in densifying magma. Earth Planet Sci Lett 429:223-233

Iverson RM, Dzurisin D, Gardner CA, Gerlach TM, LaHusen RG, Lisowski M, Major JJ, Malone SD, Messerich JA, Moran SC, Pallister JS, Qamar AI, Schilling SP, Vallance JW (2006) Dynamics of seismogenic volcanic extrusion at Mount St Helens in 2004-05. Nature 444(7118):439-443

Kendrick JE, Lavallee Y, Hess KU, Heap MJ, Gaunt HE, Meredith PG, Dingwell DB (2013) Tracking the permeable porous network during strain-dependent magmatic flow. J Volcanol Geotherm Res 260: $117-126$

Kennedy BM, Jellinek AM, Russell JK, Nichols ARL, Vigouroux N (2010) Time-and temperature-dependent conduit wall porosity: a key control on degassing and explosivity at Tarawera volcano, New Zealand. Earth Planet Sci Lett 299(1-2):126-137

Lavallée Y, Hess K-U, Cordonnier B, Bruce Dingwell D (2007) NonNewtonian rheological law for highly crystalline dome lavas. Geology 35(9):843-846

Lavallee Y, Benson PM, Heap MJ, Hess K-U, Flaws A, Schillinger B, Meredith PG, Dingwell DB (2013) Reconstructing magma failure and the degassing network of dome-building eruptions. Geology 41(4):515-518

Martel C, Schmidt B (2003) Decompression experiments as an insight into ascent rates of silicic magmas. Contrib Mineral Petrol 144(4): $397-415$

Melnik O, Sparks RSJ (1999) Nonlinear dynamics of lava dome extrusion. Nature 402(6757):37-41

Meredith PG, Brantut N (2015) Strength recovery and vein growth during self-sealing of faults in Westerly granite, In: The Geology of Geomechanics, '9, Geol. Soc. London, October 2015.

Moore DE, Lockner DA, Byerlee JD (1994) Reduction of permeability in granite at elevated temperatures. Science 265(5178):1558-1561

Morrow CA, Moore DE, Lockner DA (2001) Permeability reduction in granite under hydrothermal conditions. J Geophys Res Solid Earth 106(B12):30551-30560

Mueller S, Melnik O, Spieler O, Scheu B, Dingwell DB (2005) Permeability and degassing of dome lavas undergoing rapid decompression: an experimental determination. Bull Volcanol 67:526-538

Mullineaux DR, Crandell DR (1981) The eruptive history of Mount St. Helens. In: Lipman P, Mullineaux D (eds) The 1980 Eruptions of Mount St. Helens, Washington: U.S. Geological Survey Professional Paper 1250. p 884

Nara Y, Meredith PG, Yoneda T, Kaneko K (2010) Influence of macrofractures and micro-fractures on permeability and elastic wave velocities in basalt at elevated pressure. Tectonophysics 503:52-59

Pallister JS, Thornber CR, Cashman KV, Clynne MA, Lowers HA, Mandeville CW, Brownfield IK, Meeker GP (2008) Petrology of the 2004-2006 Mount St Helens lava dome-implications for magmatic plumbing and eruption triggering. In: Sherrod DR, Scott WE, Stauffer PH (eds) A Volcano Rekindled: The Renewed Eruption of
Mount St. Helens, 2004-2006. U.S. Geological Survey, (pp 647703)

Pallister JS, Cashman KV, Hagstrum JT, Beeler NM, Moran SC, Denlinger RP (2013) Faulting within the Mount St. Helens conduit and implications for volcanic earthquakes. Geol Soc Am Bull 125(3-4):359-376

Pazos FA, Bhaya A, Compan ALM (2009) Calculation of Klinkenberg permeability, slip factor and turbulence factor of core plugs via nonlinear regression. J Pet Sci Eng 67:159-167

Rempe M, Smith SAF, Ferri F, Mitchel TM, Di Toro G (2014) Clastcortex aggregates in experimental and natural calcite-bearing fault zones. J Struct Geol 68(Part A):142-157

Richter D, Simmons G (1974) Thermal expansion behavior of igneous rocks. Int J Rock Mech Min Sci Geomech Abstr 11(10):403-411

Richter G, Wassermann J, Zimmer M, Ohrnberger M (2004) Correlation of seismic activity and fumarole temperature at the Mt. Merapi volcano (Indonesia) in 2000. J Volcanol Geotherm Res 135(4):331-342

Rocchi V, Sammonds PR, Kilburn CRJ (2004) Fracturing of Etnean and Vesuvian rocks at high temperatures and low pressures. J Volcanol Geotherm Res 132(2-3):137-157

Sammonds, P.R., Ayling, M.R., Meredith, P.G., Murrell, S.A.F., Jones, C., 1989. A laboratory investigation of acoustic emission and elastic wave velocity changes during rock failure under triaxial stresses, In Rock at Great Depth, vol. 1 (pp. 233-240), AA Balkema, Netherlands

Scott WE, Sherrod DR, Gardner CA (2008) Overview of 2004 to 2005, and Continuing, Eruption of Mount St. Helens, Washington. In: Sherrod DR, Scott WE, Stauffer PH (eds) A Volcano Rekindled: The Renewed Eruption of Mount St. Helens, 2004-2006. (pp 322) U.S. Geological Survey

Smith R, Sammonds PR, Kilburn CRJ (2009) Fracturing of volcanic systems: experimental insights into pre-eruptive conditions. Earth Planet Sci Lett 280(1-4):211-219

Smith R, Sammonds PR, Tuffen H, Meredith PG (2011) Evolution of the mechanics of the 2004-2008 Mt. St Helens lava dome with time and temperature. Earth and Planet Sci Lett 307(1-2):191-200

Sparks RSJ (1997) Causes and consequences of pressurisation in lava dome eruptions. Earth Planet Sci Lett 150(3-4):177-189

Sparks RSJ (2003) Dynamics of magma degassing. In: Oppenheimer C, Pyle DM, Barclay J (eds) Volcanic degassing. Geological Soc Publishing House, Bath, pp 5-22

Tanikawa W, Shimamoto T (2009) Comparison of Klinkenberg-corrected gas permeability and water permeability in sedimentary rocks. Int $\mathrm{J}$ Rock Mech Min Sci 46:229-238

Tenthorey E, Cox SF, Todd HF (2003) Evolution of strength recovery and permeability during fluid-rock reaction in experimental fault zones. Earth Planet Sci Lett 206:161-172

Thornber, C. R., J. S. Pallister, H. A. Lowers, M. C. Rowe, C. W. Mandeville, and G. P. Meeker, 2008, Chemistry, mineralogy, and petrology of Amphibolein Mount St. Helens 2004-2006 Dacite, In D. R. Sherrod, W. E. Scott, and P. H. Stauffer, eds., A Volcano Rekindled: The Renewed Eruption of Mount St. Helens, 20042006.: Professional Paper, (p. 727-754) U.S. Geological Survey.

Vinciguerra S, Trovato C, Meredith PG, Benson PM (2005) Relating seismic velocities, thermal cracking and permeability in Mt. Etna and Iceland basalts. Int J Rock Mech Min Sci 42:900-910

Woods AW, Koyaguchi T (1994) Transitions between explosive and effusive eruptions of silicic magmas. Nature 370(6491):641-644

Wooster MJ, Kaneko T (1998) Satellite thermal analyses of lava dome effusion rates at Unzen Volcano, Japan. J Geophys Res Solid Earth 103(B9):20935-20947

Zharikov AV, Vitovtova VM, Shmonov VM, Grafchikov AA (2003) Permeability of the rocks from the Kola superdeep borehole at high temperature and pressure: implication to fluid dynamics in the continental crust. Tectonophysics 370(1-4):177-191 